\title{
Synergistic effect of silver nanoparticles (AgNPs) and gentamicin against clinical isolates of Pseudomona aeruginosa
}

\author{
Somayeh Esmaili ${ }^{1}$, Reza Hosseini Doust ${ }^{2}$ \\ ${ }^{1}$ MSc Student, Department of Microbiology, Faculty of Advance Science and Technology Tehran Medical Sciences, \\ Islamic Azad University, Tehran, Iran \\ ${ }^{2}$ Professor, Department of Microbiology, Faculty of Advanced Science \& Technology Tehran Medical Sciences, \\ Islamic Azad University, Tehran, Iran
}

\begin{abstract}
Background: Pseudomona aeruginosa is one of the most important opportunistic pathogens and is one of the main causes of nosocomial infections. Antibiotic therapy has faced with serious problem due to worldwide antibiotic resistance of this organism. The purpose of this study was to evaluate the anti-bacteial effects of AgNPs on Gentamicin against clinical isolate of P. aeruginosa.

Materials and methods: Sixty strains of $P$. aeruginosa were isolated from blood, wound, respiratory specimens collected from hospitalized patients within Tehran hospitals. All isolates were first confirmed using standard bacteriologic tests. Standard Kirby- Bauer agar diffusion method was used to evaluate the gentamycin resistance pattern of isolates and also their sensitivity pattern to different concentrations of AgNPs. Finally the effects of different combinations of gentamycin and AgNPs on P. aeruginosa were tested and the results were analyzed by statistical methods.

Results: More than $56 \%$ of isolates were resistant to gentamicin, and $13 \%$ were mentioned as intermediate according to CLSI guidelines. $30 \%$ of isolates were sensitive to this antibiotic. Almost all isolates were sensitive to AgNPs at concentrations of up to $10 \mu \mathrm{g} / \mathrm{ml}$. The ratio of 50:50 of gentamycin and AgNPs sowed efficacy against all clinical isolates and standard.

Conclusion: we concluded that AGNps enhanced anti-bacterial effects of gentamycin at different ratio of two components. The best effects observed when antibiotic and AgNPs were mixed equally at their MIC level. We assumed that different size of AgNPs should be tested with antibiotic before final recommendation.

Keywords: Synergic, Antibiotic resistance, P. aeruginosa, Gentamicin, Silver nanoparticles.
\end{abstract}

Cited as: Esmaili S, Hosseini Doust R. Synergistic effect of silver nanoparticles (AgNPs) and gentamicin against clinical isolates of P. aeruginosa. Medical Science Journal of Islamic Azad University, Tehran Medical Branch 2019; 29(1): 64-70.

Correspondence to: Reza Hosseini Doust

Tel: +989121952654

E-mail: rhdoust@gmail.com

ORCID ID: 0000-0002-9749-1250

Received: 14 Feb 2018; Accepted: 17 Jun 2018 
مجله علوم :زشكى دانشخاه آزاد اسلامى

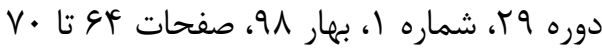

Original

Article

\section{اثر سينرزيك نانو ذرات نقره (AgNPs) و جنتامايسين برعليه جدايههاى بالينى سودوموناس آئروزينوزا}

\section{سميه اسماعيلى'، سيد رضا حسينى دوست}

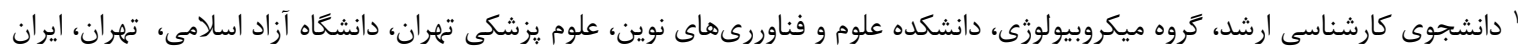

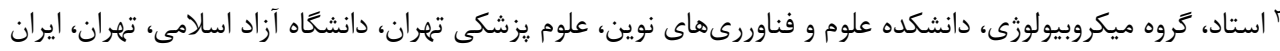

\section{جكيده}

سابقه و هدف: سودوموناس آئروزينوز/ يكى /ز مهمترين ياتوزنهاى فرصت طلب و /ز جمله عوامل اصلى عفونتهاى بيمارستانى

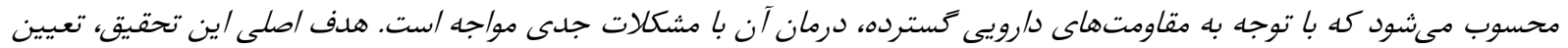

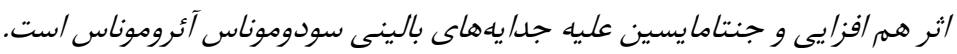

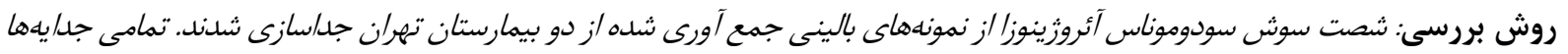

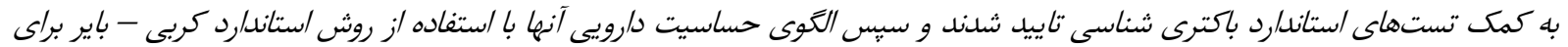

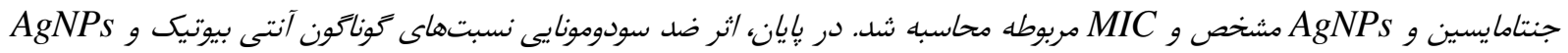
بررسى ونتايج/زنظر آمارى تحليل شد.

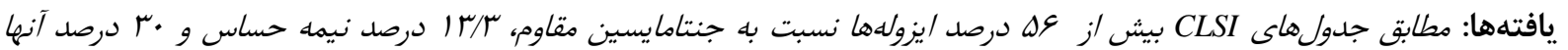

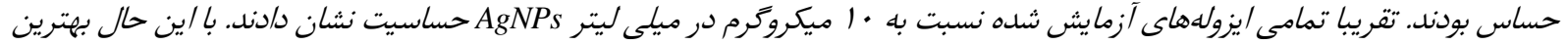

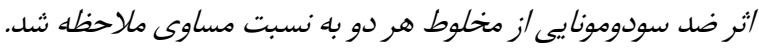

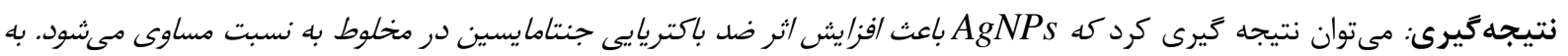

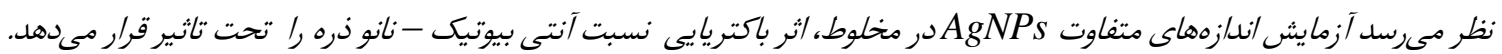

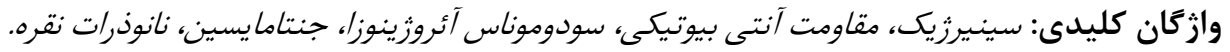

دراثر عفونتهاى بيمارستانى در دنيا كزارش شده است. مقدمه

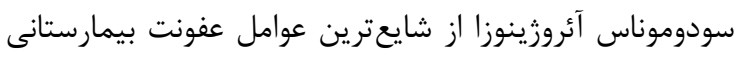

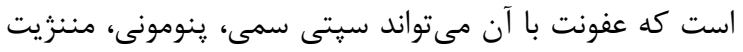

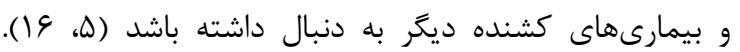
سودوموناس داراى مقاومتى ذاتى نسبت به طيف وسيعى از مواد ضد ميكروبى و ضد عفونى كننده، مانند تركيبات آمونيوم،

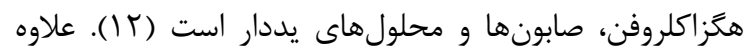

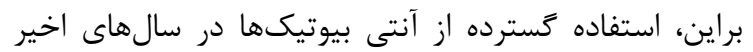

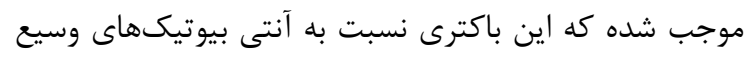

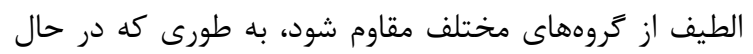
عفونتهاى بيمارستانى يكى از معضلات مطرح يزشكى در

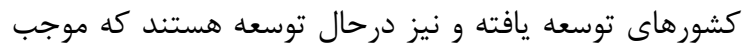

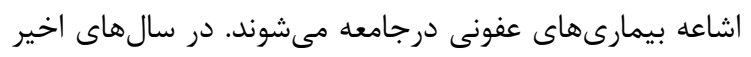

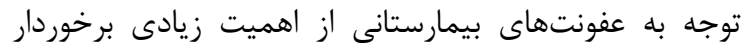

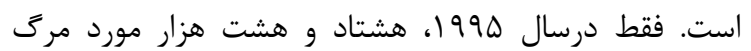

آدرس نويسنده مسئول: تهران، دانشكاه آزاد اسلامى، علوم يزشكى تهران، دانشكده علـوم و فنـاوررىهـاى

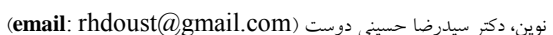
ORCID ID: 0000-0002-9749-1250 تاريخ دريافت مقاله: تاريخ بذيرش مقاله: تاريخ دربافت مقال 


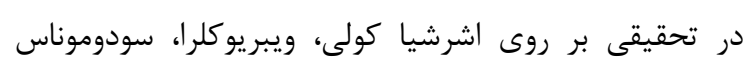

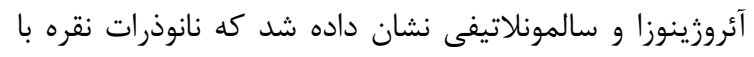

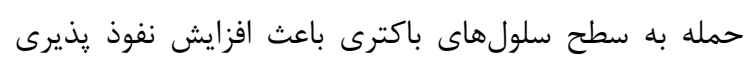

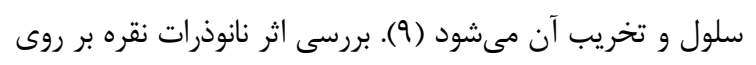

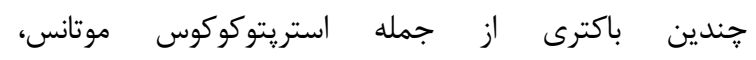

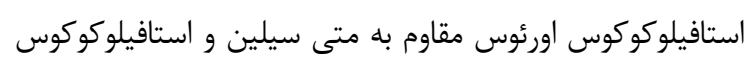

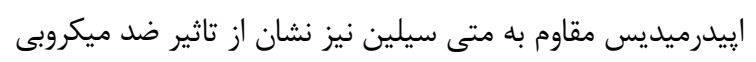

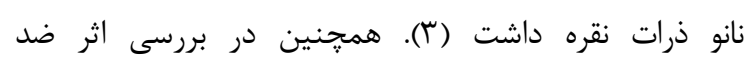

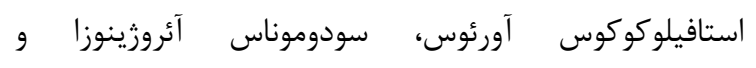

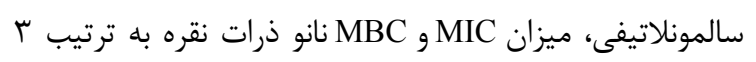

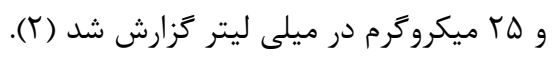

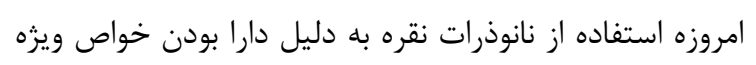

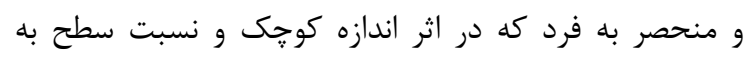

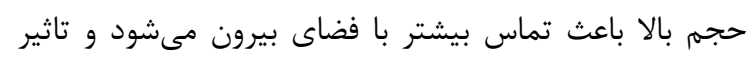

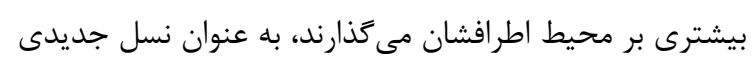
از داروهاى ضدباكتريايى به طور قابل توجهى رايج شده است است.

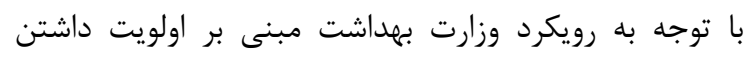

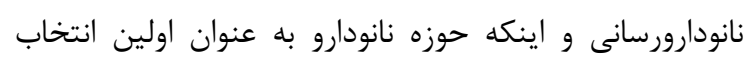

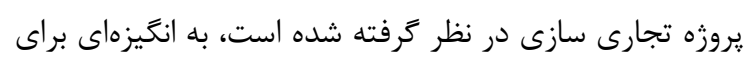

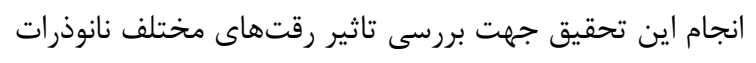

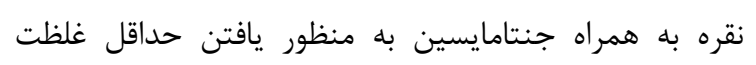

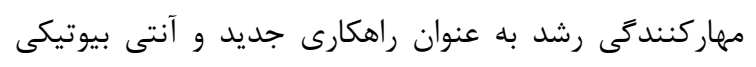
موثر براى درمان عفونت هاى ناشى از سودوموناس آنروزينوزا

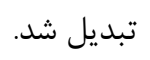

\section{مواد و روشها}

در اين مطالعه، دريك بازه زمانى سه ماهد، از بخش سوانه

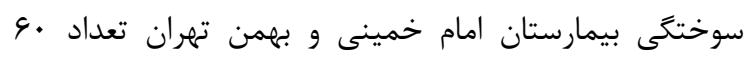

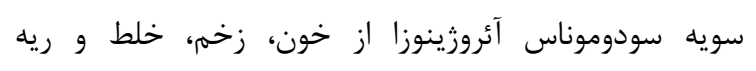

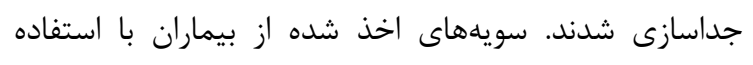

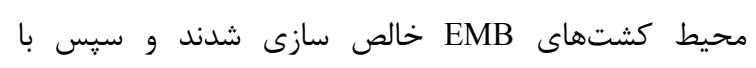

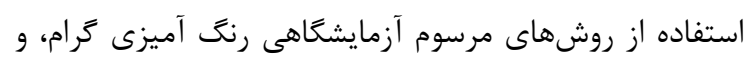

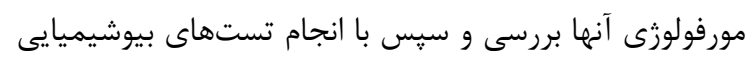

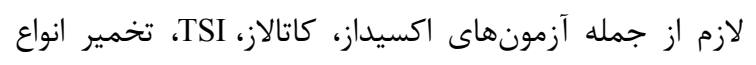

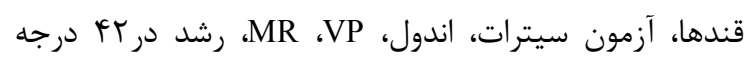

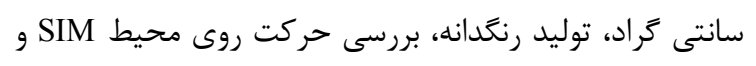

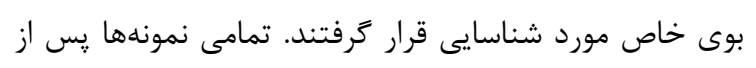
تشخيص و تاييد نهايى در محيط ترييتيكيس سوى برى براث

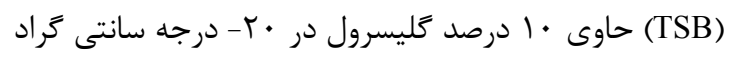

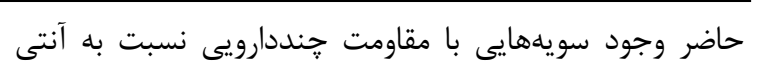

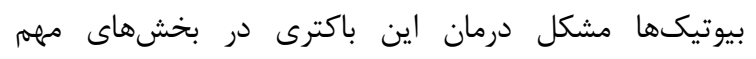

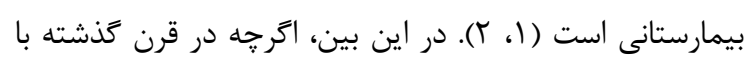

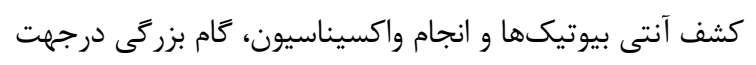

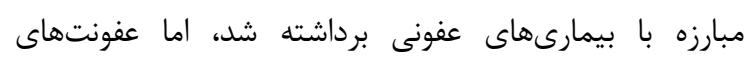

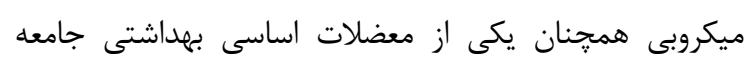

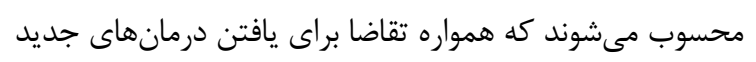

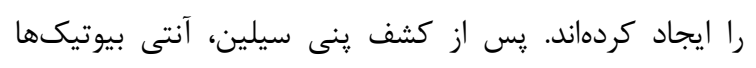

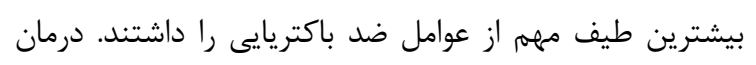

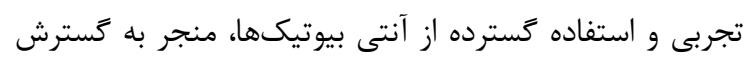

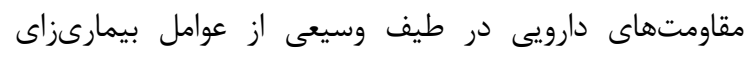

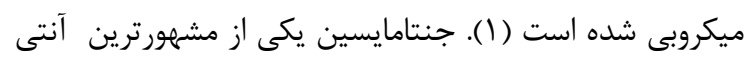

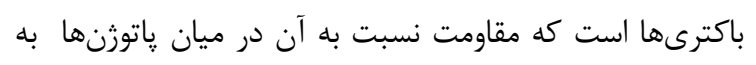

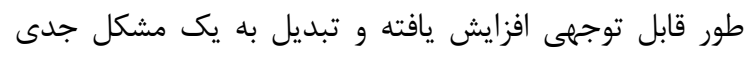

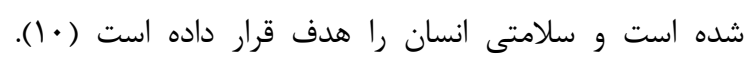

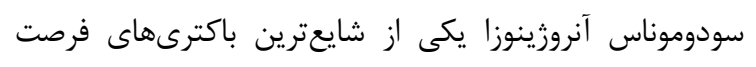

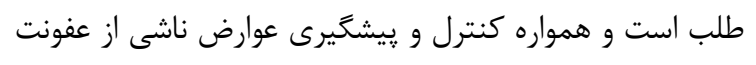

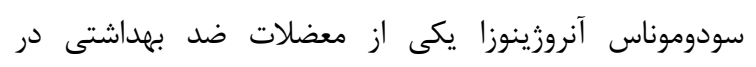
عفونتهاى بيمارستانى در سراسر جهان به شمار مىرود، زيرا

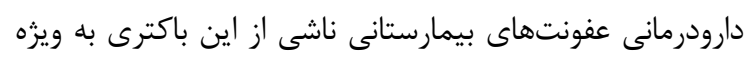

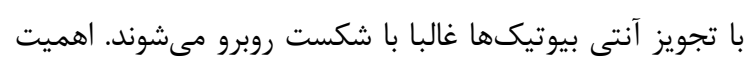

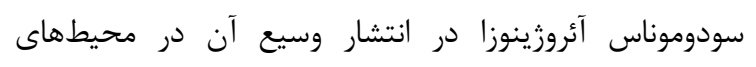

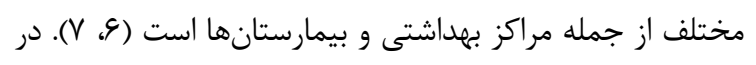

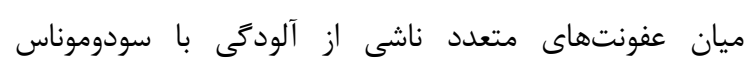

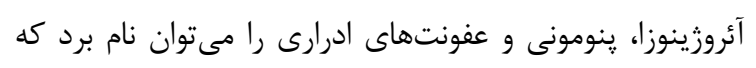

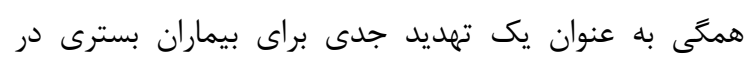

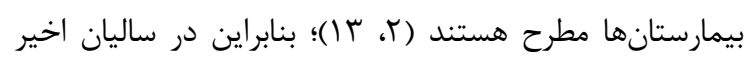
تلاشهاى قابل توجهى در راستاى تحقيق و توسعه داروهاى جايكزين شده است. از سويى نيز مطالعات بالينى كمى براى تردي تعيين درمان مطلوب

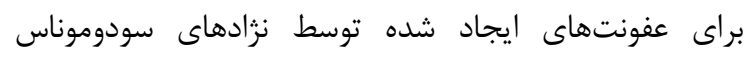

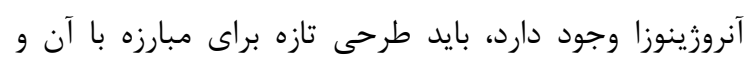

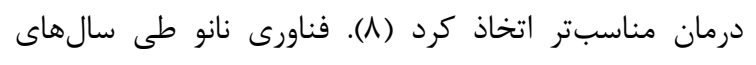

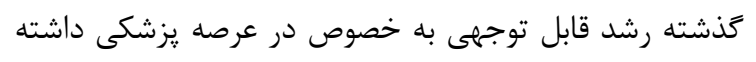

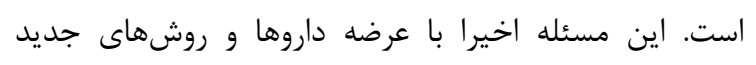

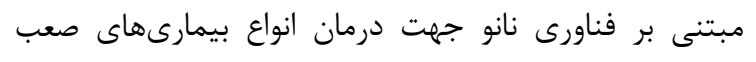

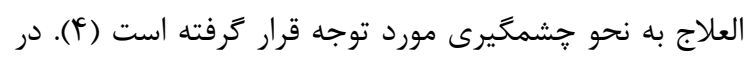

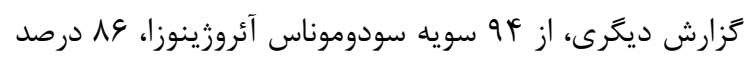

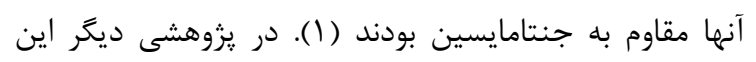
ميزان الها له درصد كزارش شد (1) (1). 


\begin{tabular}{|c|c|c|c|c|c|}
\hline \multicolumn{2}{|c|}{$\mathrm{MIC}$} & \multirow{2}{*}{$\begin{array}{c}\text { الكوى حساسيت (ميلى متر) } \\
\end{array}$} & \multicolumn{2}{|c|}{ قطر هاله عدم رشد (IZ) } & \multirow[t]{2}{*}{ لكَوى حساسيت (ميلى متر) } \\
\hline درصد & فراوانى & & درصد & فراوانى & \\
\hline$\Delta \cdot$ & $r$. & $(\mathrm{R}) \geq 19$ & $\Delta \xi / V$ & Mr & $12 \leq(\mathrm{R})$ \\
\hline$r$. & ir & $(\mathrm{I})(\wedge)$ & r & $\wedge$ & $13-14$ (I) \\
\hline \multirow[t]{2}{*}{$r}$. & 11 & $(S) \leq f$ & r. & 11 & $15 \geq(\mathrm{S})$ \\
\hline & & حساس (11) & & & 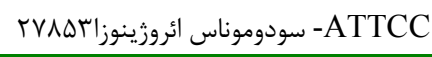 \\
\hline
\end{tabular}

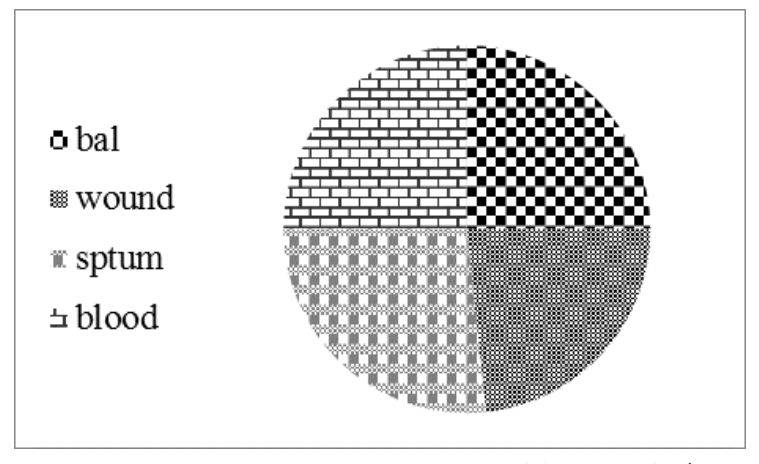

نمودار ا. توزيع فراوانى نمونههاى مورد بررسى

نتايج الكوى حساسيت و قطر هاله عدم رشد ايزولهها نسبت به جنتامايسين نشان مىدهد كه قطر هاله عدم رشـد • ب ايزولـه

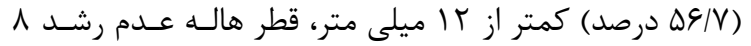

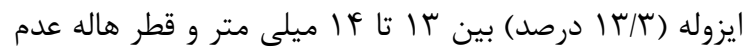
رشد \| ايزوله (•r درصد) بيشتر از ها ميلى متر بود. نتـايج الكوى حساسيت ايزولهها نسبت به جنتامايسين به روش

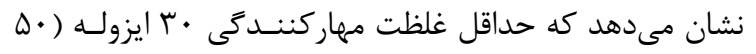

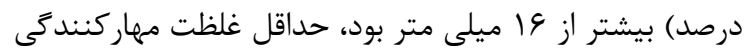

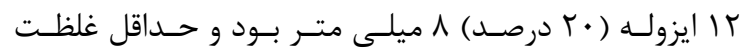
مهاركنند

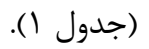
ميانگين قطر هاله عدم رشد (IZ) ايزولهها در تمــاس بــا

\section{غلظتهاى مختلف نانو ذرات نقره} همان طور كه در نمودار r مشاهده مىشود، ميانگين قطر هاله

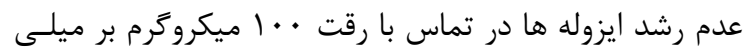

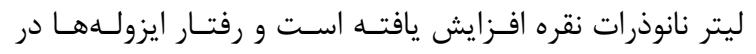

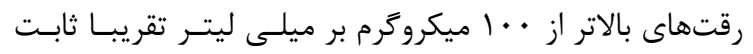

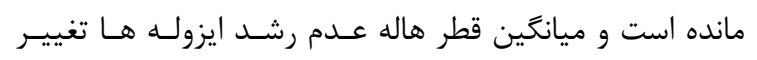

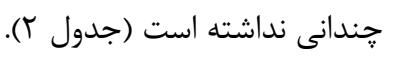

نخمهدارى شده تا در فرآيندهاى بعدى مورد استفاده قرارگيرند.

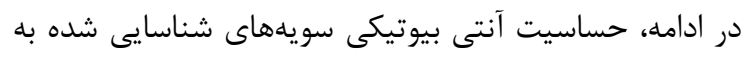
روش انتشار ديسك در آتار با استفاده از ديسكهاى تهيه شده، درمحيط مولرهينتون آتار مورد بررسى قرار ترفت. بدين منظور باكترى و ديسك محتوى جنتامايسين را در مر مرينتون محيط مولر هينتون آكار قرار داده و سيس در در انكوباتور

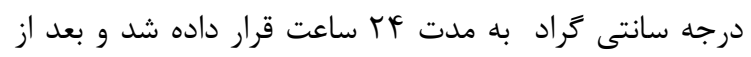

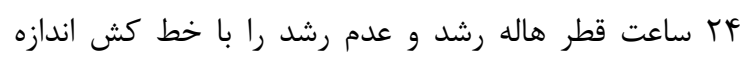
كيرى شد و در نهايت وضعيت حساسيت سويهها را نسبت به

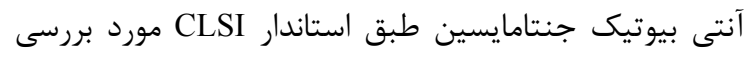

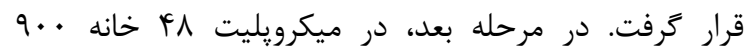
ميكروليتر سوسيانسيون باكترى و • •ا ميكرو ليتر نانوذرات نقره اضافه كرده و Fr ساعت داخل انكوباتور س دV درجه قرار

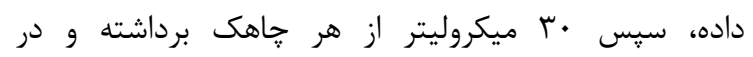

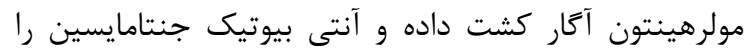

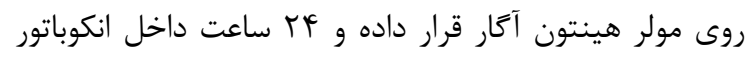

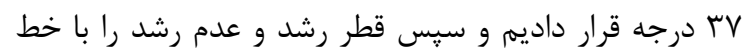
كش اندازه گيرى كرديم. MIC نانو ذرات نقره و جنتامايسين مطابق روشهاى استاندارد از هر يك از عوامل رقت سريالى از

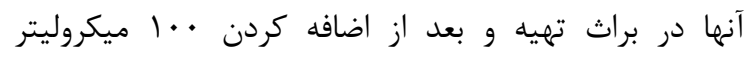

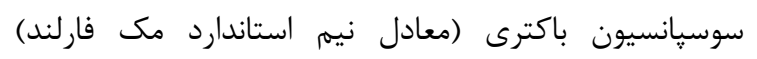
گرمخانه گذارى شده و يس از باكترى در لولههاى مختلف قرائت و دادههاى به دست آمده

تحليل شدند.

\section{بافتهها}

در نمودار ا، توزيع نمونههاى مورد مطالعه مشاهده مسىشـود،

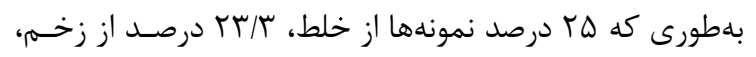
r r/V 


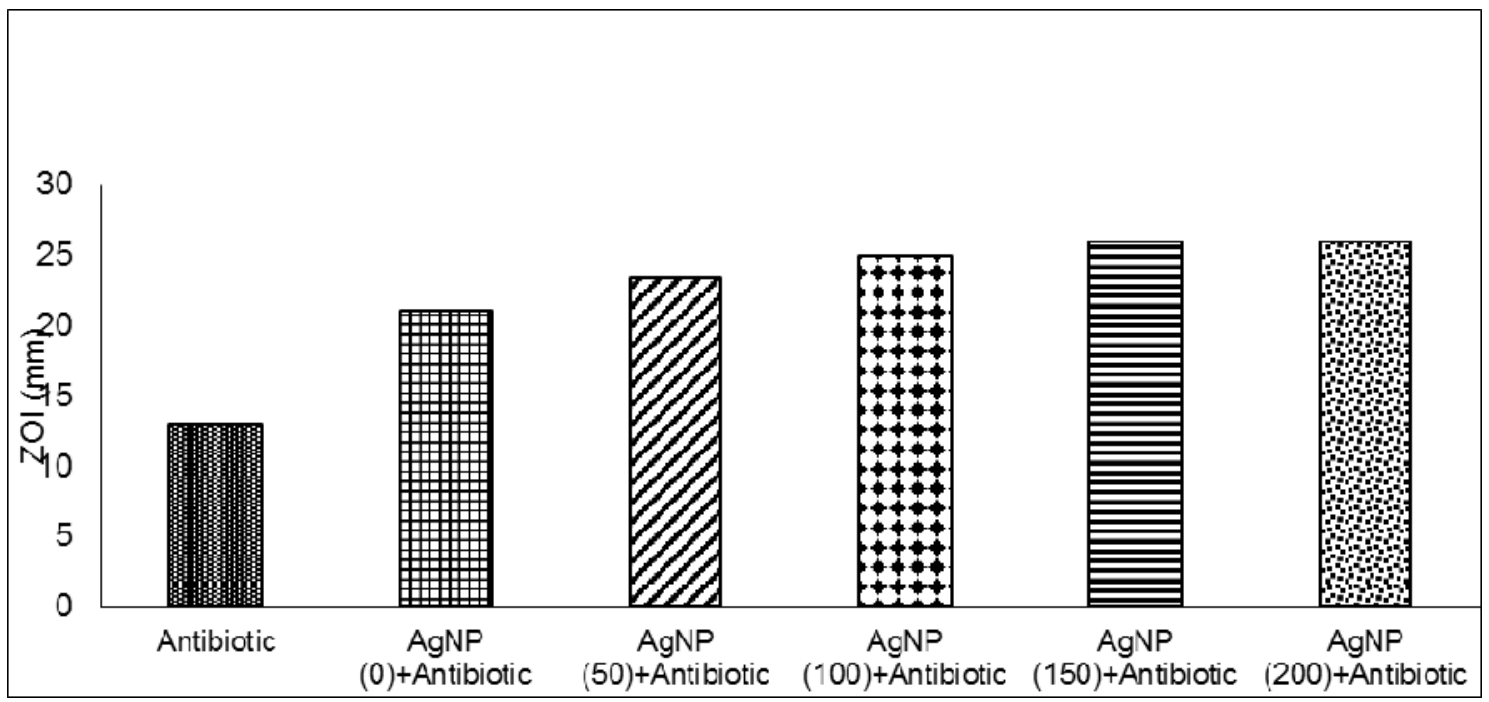

نمودار r. ميانگين قطر هاله عدم رشد ايزولهها در مقابل جنتامايسين و جنتامايسين به اضافه نانوذرات نقره در غلظتهاى مختلف

بحث

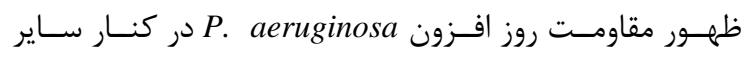
باكترىهاى بيمارىزا نسبت به عوامل ضد ميكروبى، به عنـوان

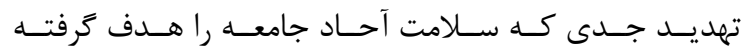

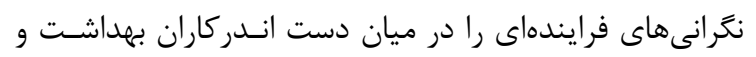

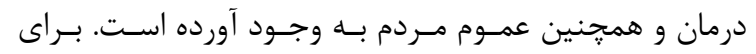

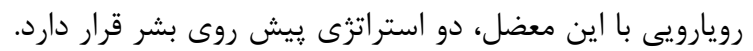

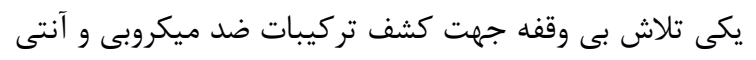

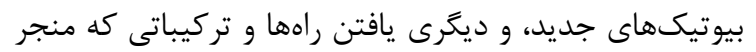

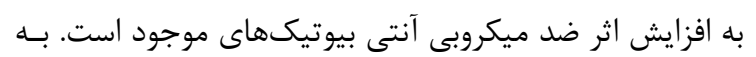

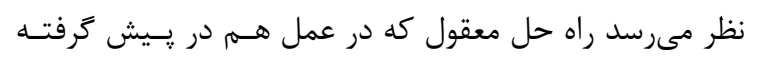
شده تلاش در راستاى هر دو استراتزى است. تحقيقات نســـتا

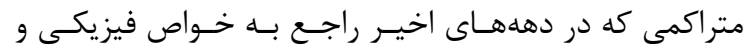

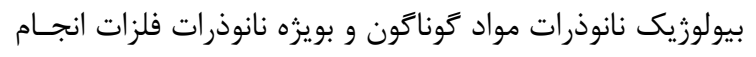

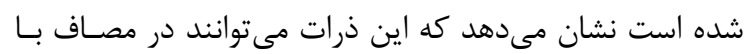

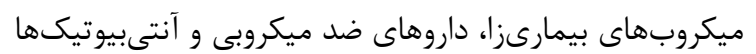

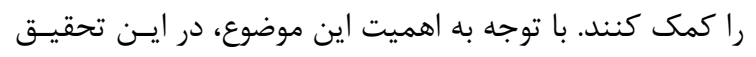
اثر هم افزايى AGNPs بر جنتامايسين بررسى شد.

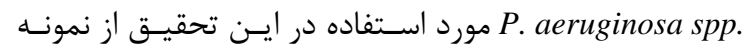

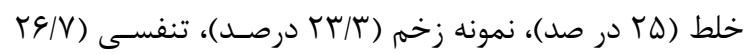

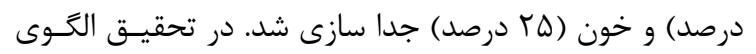

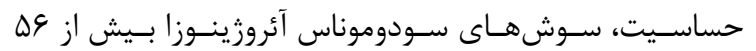

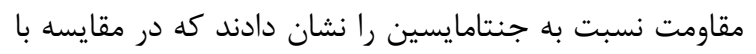
كزارشهاى مشابه، ولى در زمان هاى مخالف، كمى مانى كمتر است.

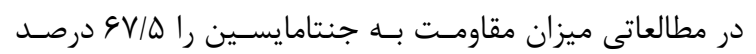

جدول r. ميانگَين قطر هاله عدم رشد (IZ) ايزوله ها در تمـاس بـاـ

\begin{tabular}{|c|c|}
\hline ميانكَين قطر هاله عدم رشد & غلظت هاى مختلف نانو ذرات نقره \\
\hline $9 / 9$ & . \\
\hline $1 \pi / \pi$ & $\Delta$. \\
\hline$r I / r$ & $1 \ldots$ \\
\hline$r / / N$ & 10. \\
\hline$r \mid / \Lambda$ & r.. \\
\hline
\end{tabular}

جدول r. ميانكين قطر هاله عدم رشد (IZ) ايزوله ها در تمـاس بـاـ

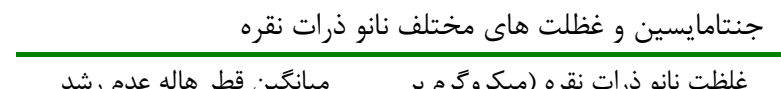
(IZ) ميلى ليتر)

\begin{tabular}{cc}
\hline$r / \Delta$ & $\cdot$ \\
\hline$r / 4$ & $\Delta$. \\
$r r / q$ & $1 .$. \\
$r \Delta / \Lambda$ & $1 \omega$. \\
$r \Delta / 9$ & $r$. \\
\hline
\end{tabular}

هنخامى كه ايزولـههـا در تمـاس بـا جنتامايسـين و رقـتهــاى مختلف نانو ذرات نقره قرار كرفتند، نتايج نشان داد كه با با افزايش

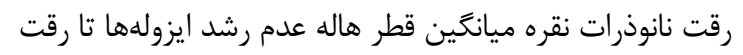

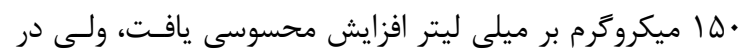

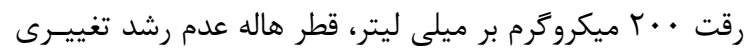

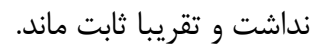




\begin{tabular}{|c|c|}
\hline در سال ه • ·؟ فعاليت ضد باكتريايى نـانو ذرات نقــه را عليـه & كزارش كردهاند (ז، ا). مقاومت ايزولههاى بالينى سـودوموناس \\
\hline جهار نوع از باكترى هاى كرم منفى اشرشيا كـولى، ويبريـوكلرا، & آئروزينوزا نسبت به جنتامايسين // ه درصد نيز كزارش شده \\
\hline سودوموناس آئروزينوزا و سالمونلاتيفى مورد بررسى قرار دادند. & است. با نحاه اجمالى به كزارشها حذشته مىتوان نتيجه كرفت \\
\hline نتايج حاصل نشان داد كه نانو ذرات نقره بـا حملـه بـهـ سـطحح & كه ميزان مقاومت به آنتى بيوتيك هاى متفاوت در مورد سويه \\
\hline سلولهاى باكترى باعث افزايش نفوذ يذيرى سـلول و تخريـب & هاى سودوموناس آئروزينوزا نسبتا بالاســت. البتــــ ايـن نتــايج \\
\hline آن مىشوند (9).اثر نانو ذرات نقره را بر روى هنـدين بـاكترى & برحسب زمـان و مكــان مطالعـه، تفـاوت معنـــدارى را نشــان \\
\hline بيمارىزا از جمله اسـتريتوكوكوس موتـانس، اسـتافيلوكوكوس & مى دهد. ولى فرايند دائما درحال تغيير الكَوى حساسـيتهـاى \\
\hline اورئوس مقاوم به متى سيلين و استافيلوكو كوس إيبدرميـديس & آنتى بيوتيكى را نبايد از نظر دور داشت. فعاليت ضد ميكروبـى \\
\hline مقاوم به متى سيلين مورد بررسى قرار دادند و اثر مهارى رشد & غلظتهاى مختلف نانوذرات نقره كه در تحقيق حاضر ملاحظه \\
\hline 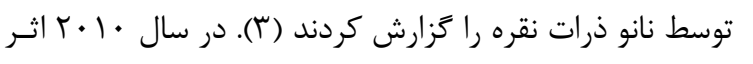 & 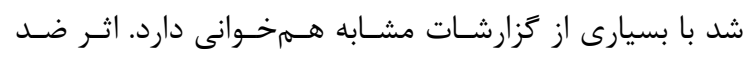 \\
\hline ضد باكتريايى نانوذرات نقره عليه باكترىهاى استافيلوكوكوس & باكتريايى نانوذرات نقره عليه سودوموناس آئروزينوزا نيـز قـبلا \\
\hline آورئوس آئروزينوزا و سالمونلاتيفى موريوم بررسى شـد. نتـايج & 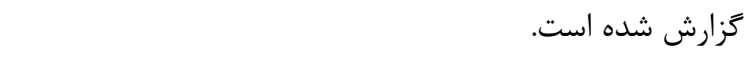 \\
\hline آنها نشان داد كه نانو ذرات نقـــه داراى فعاليـت ضـد بــاكترى & آدابى و همكارانش در تحقيقـى بــا عنـوان "بررسـى و تعيـين \\
\hline شديدى عليه باكترىهاى مذكور هستندف به طورى كه ميزان & 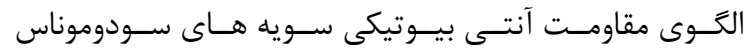 \\
\hline 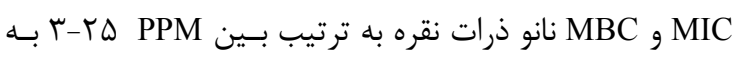 & 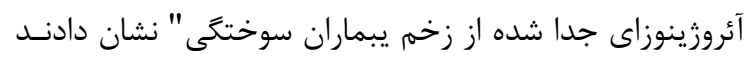 \\
\hline 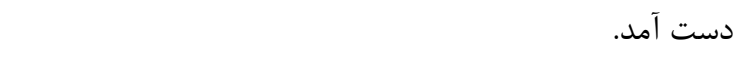 & 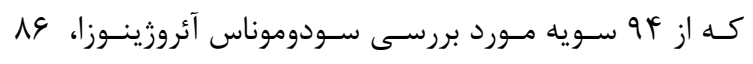 \\
\hline از اين مطالعه نتيجه گَيرى مىشود نانو ذره نقره مسىتوانــــــر & درصد مقاومت به آنتى بيوتيـك جنتامايسـين داشـتند (1). \\
\hline رشد سوشهاى بيمارستانى سودوموناس آئروزينوزا اثر بـــذارد & ن نتايج تحقيق رجب يـور و همكـارانش پيرامـون ارزيـابى \\
\hline و به خصوص فعاليت ضد سودوموناسى جنتامايسين را افزايش & سيت ايزوله هاى بالينى سودوموناس آئروزينوزا نسبت بــهـ \\
\hline دهد. موضوعى كه در صورت ادامه تحقيقات و تاييد نتايج اوليه & 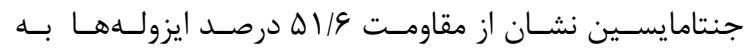 \\
\hline شايد بتواند در پِيشخيرى از سيل مقاومت دارويى اين بـاكترى & 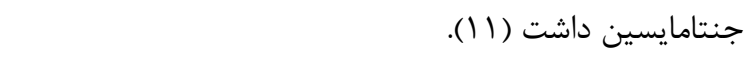 \\
\hline & \\
\hline
\end{tabular}

\section{REFERENCES}

1. Hosseini Doust R, Saberi M, Hosseini MJ, Mohabati Mobarez A. Surveillance of current antibiotic resistance among clinical isolates S. aureus, E. coli and P. aeroginosa collected from five Iranian cities. JPSH 2012;1:27-38.

2. Nazari Monazam A, Hosseini Doust SR, Mirnejad R. Prevalence Per and VEB beta-lactamase genes among Acinetobacte baumanni isolated from patients in Tehran by PCR. Iran J Med Microbiol 2014;8;28-35.

3 .Adabi M, Talebi Taher M, Arbabi L, Afshar M, Fathizadeh S, Minaeian S, et al. Determination of Antibiotic Resistance Pattern of Pseudomonas aeruginosa Strains Isolated from Patients with Burn Wounds. J Ardabil Univ Med Sci 2015;15:66-74.

4. Mahan C, Manuselis G. A textbook of Diagnostic microbiology. London :W.B Sounders compony, 1995.

5. Cristobal LF, Martinez-Castanon GA, Martinez-Castanon RE, Loyola- Rodriguez JP, Patino-Marin N, Reyes-Macias JF, et al. Antibacterial effect of silver nanoparticles against Strptococcus mutans. Mater Lett 2009;63:2603-6.

6. Couvreur P, Vauthier C. Nanotechnology: intelligent design to treat complex disease. Pharm Res 2006;23:1417-50.

7. Eriksen HM, Iversen BG, Aavitsland P. Prevalence of nosocomial infections in hospitals in Norway, 2002 and 2003. J Hosp Infect 2005;60:40-5.

8. Benneth JE, Dolin R. Principles and practice of affection disease. London: Churchill Livingston, 1995.

9. Douglas MW, Mulholland K, Denyer V, Gottlieb T. Multi-drug resistant pseudo monas Aeruginofa outbreak and a burn unit. Burns 2001;27:131-5.

10. Mirsalehian A, Feyzabadi M. Nakhjavani FA. Jabal Ameli F, Goli H, Kalantari N. Detection ofVEB-1, OXA-10 and PER-1 genotypes in extended-spectrum beta-lactamase- producing Pseudomonas aeruginosa strains isolated from burn patients. Burns 2010;36:70-4.

11. Morones JR, Elechiguerra JL, Camacho A, Holt K, Kouri JB, Ramírez JT, et al. The bactericidal effect of silver nanoparticles. Nanotechnology 2005;16:2346-53. 
12. Pitout JD, Sanders CC, Sanders WE Jr. Antimicrobial resistance with focus on beta-lactam resistance in gramnegative bacilli. Am J Med 1997;103:51-9.

13. Rajabpour M, Arabestani MR, Yousefi mashof R, Alikhani MY. MIC determination of Pseudomonas aeruginosa strains were isolated from clinical specimens of patients admitted to educational hospitals in Hamedan (90-91). Iran J Med Microbiol 2013;7:18-25.

14. Shahcheraghi F, Nikbin VS, Feizabadi MM. Prevalence of ESBLS Gene among Multidrug-Resistant Isolates of Pseudomonas aeruginosa Isolated from Patients in Tehran. Microbe Drug Resist 2009;15:37-9.

15. Joklik WK, Willett HP, Amos DB, Wilfert CM, Zinsser H. Zinsser Microbiology, 20th Edition, Appleton and Lange, 1992.

16. Mirzai E, Hosseini Doust R, Mirnejad R, Haghighat S, Rabiei HR. Prevalence of Wide-Spectrum betalactamase genes (KPC, NDM) in clinical isolates of A. baumannii. Tropical Medicine and Infection Disease 2014;19;61-9. 